preparations, using the Somogyi reagent $t^{4}$, showed that the addition of a dormant embryo extract had no inhibitory effect. It would appear, therefore, that sucrase is synthesized in the embryonic tissues in the early stages of germination, and it is probably not present in a latent form in the dormant tissues. Hora $^{5}$ has also demonstrated sucrase formation in germinating barley. Germinated embryo preparations $\left(p \mathrm{H} 5.6 ; 35^{\circ}\right.$ C. ; $48 \mathrm{hr}$.) degraded stachyose and verbascose with the liberation of galactose, glucose and fructose in both cases. With dormant cotyledon preparations under the same conditions, however, the only free monosaccharide liberated was galactose.

During these studies it was observed that the suc. rase in germinated embryos was strongly inhibited (at $10^{-8} M$ concentrations) by mercuric chloride and phenylmercuric acetate and to a lesser extent by iodoacetic acid. An aqueous extract of the bean testas also behaved as an inhibitor.

The role of sucrase in the plant is not understood. In the case of the germinating bean seed the increase in reducing substences together with the appearance of sucrase activity may be significant. The rapid disappearance of galactose-containing oligosaccharides from the germinating tissues and the absence of significant quantitios of free galactose suggest that the former compounds may form an important sugar reserve for the developing plant.

A full report of this work will be given in a later publication.

I wish to thank Prof. E. L. Hirst for helpful discussions, Prof. E. J. Bourne for valuable suggestions and Prof. J. E. Courtois for a specimen of verbascase.

Department of Chemistry, Royal Holloway College

(University of London), Englefield Green, Surrey. Oct. 3.

${ }^{1}$ Hough, L., Jones, J. K. N., and Wadman, W. H., J. Chem. Soc. 1702 (1950)

\& Kawamura, S., Tsuboi, Y., and Nakamura, H., Tech. Bull. Kagawa Agric. Coll.' (Japan), 6, 27 (1954).

${ }^{3}$ Whistler, R. L., and Durso, D. F., J. Amer. Chem. Soc., 72, 677 (1950).

' Somogyi, M., J. Biol. Chem., 195, 19 (1952).

'Hora, F. B., D.Phil. thesis (Oxford, 1936).

\section{Inhibition of Sulphate Reduction in Paddy Soils}

The hydrogen sulphide formed in waterlogged soils is a serious problem in rice cultivation. It inhibits the uptake of water and nutrients, and may even cause root-rot ${ }^{2-5}$. The disease due to these injurious effects (browning disease, 'brusone', brand, aki-ochi, etc.) in unfavourable weather conditions, chiefly too little sun (1949, 1954 and 1955), caused considerable damage in Hungary. Injury appeared mainly after stem elongation, when the oxygen supply to the roots is greatly reduced.

My previous experiments for controlling the injuries showed that results can best be obtained not by binding the hydrogen sulphide, but by preventing its formation. It is formod mainly by reduction of sulphate, for which the cellulose-butyric acid fermentation provides the hydrogen source $e^{5,6}$.

To eliminate the hydrogen required for the reduction, experiments were carried out in the laboratory and in the field. $1.5 \mathrm{gm}$. cotton was placed between wet rice soil-disks in containers after soaking in 30-80 mgm. per cent ammonium and sodium sulphates or in 30-50 mgm. per cent ammonium or potassium nitrate. 14 days after waterlogging and incubation 8.8-26.0 mgm. sulphide per container was formed in the controls and in the containers with sulphates. No sulphide was found in the containers with nitrates.

The atomic hydrogen, formed by butyric acid fermentation, is used to reduce nitrate, and, consequently, cannot be utilized by the sulphate-reducing bacteria as a source of energy.

Experiments in the field also yielded positive results : for this purpose ammonium nitrate mixed with powdered lime ('Péti só') proved to be the most suitable.

Institute for Plant Physiology,

R. VÁMOS

University of Szeged. Sept. 8.

${ }^{1}$ Alberda, Th., Plant and Soil, 5, 11 (1953).

'Baba, I., Iwata, I., and Takahasi, Y., Soil and Fertilizers, 6, 359 (1957).

Mitsui, S., Aso, S., Kumarawa, K., and Ishiwara, T., Trans. Fifth Int. Congr. Soil Sci., 2, 364 (1954).

Okajima, H., and Takagi, S., Sci. Rep. (Res. Inst. Tohoku Univ.

' Takai, J., Koyama, T., and Kamura, T., Soil and Plant Food, 2, No. 2, 63 (1956)

- Vámos, R., Acta Biol. (Szeged), 1, 113 (1955).

\section{An Aphid-transmitted Tobacco Ring-Spot-like Virus isolated from Begonia tuberhybrida}

Begonia semperflorens was reported as a host plant for tobacco ring-spot virus by Price $\theta^{1}$, but no record of natural infection of begonia with this virus is known.

A plant of Begonia tuberhybrida multiflora with leaves showing yellow spots surrounded by a necrotic line was tested for virus infection. The symptoms on tobacco plants, variety Samsun, and cucumbers, variety Blanc hâtif, inoculated with sap were similar to the symptoms described by several workers for plants infected with viruses of the tobacco ring-spot group.

The inactivation temperature in tobacco sap after $10 \mathrm{~min}$. heating was about $70^{\circ} \mathrm{C}$.

The virus was easily transmitted by $M y z u s$ persicae from tobacco to cucumber (1-2 min. acquisition feeding after $2-3 \mathrm{hr}$. starvation; $24 \mathrm{hr}$. inoculation feeding ; 10 aphids a plant).

Tobacco ring-spot viruses are not usually transmitted by aphids. McWorther" reported that a virus of this group isolated from leguminous plants was transmitted by aphids, but only in company with pea enation mosaic virus. Smith and Brierley ${ }^{3}$ reported transmission by aphids of tobacco ring-spet virus from gladiolus to gladiolus, but in conditions that did not completely secure the absence of bean yellow mosaic virus, which is prevalent in this plant.

Our results confirm that viruses of the tobacco ring-spot group can be transmitted by aphids; in our conditions, bean yellow mosaic virus was not present in combination, and the absence of cucumber mosaic virus was secured by a cross-protection test.

The virus isolated from Begonia did not protect tobacco plants against infection by the type strain of tobacco ring-spot virus.

Thanks are due to Prof. R. Vanderwalle for criticism of this work and to Dr. K. M. Smith for material infected with virus.

J. Semal

Plant Pathology Laboratory, Agronomical Institute, Gembloux, Belgium. Oct. 15.

1 Price, W. C., Amer. J. Bot., 87, 531 (1940).

${ }^{2}$ McWorther, F. P., Plant Dis, Reporter, 38, 453 (1954).

${ }^{3}$ Smith, F. F., and Brierley, P., Plant Dis. Reporter, 39, 35 (1955). 